\title{
PROTEKSI DIRI DALAM BERINTERAKSI (PRODIKSI) PADA SISWA SMPN 11 SEMARANG
}

\author{
Tiatira Evangelista ${ }^{1}$, Pradipta Christy Pratiwi ${ }^{2}$, Anggita Fathidhia Ivana ${ }^{3}$ \\ 1, 2, 3 Universitas Negeri Semarang
}

tiatirae@students.unnes.ac.id, pradiptacp@mail.unnes.ac.id, anggitafathidhia@students.unnes.ac.id

\begin{abstract}
Abstrak
Remaja merupakan fase transisi dari kanak-kanak menuju dewasa. Pada masa ini, individu mengalami berbagai perubahan, baik perubahan fisik, kognitif, dan psikososial. Salah satu tugas perkembangan psikososial pada masa remaja adalah melewati masa identity vs role confusion. Identitas diri penting untuk dimiliki seseorang agar dapat mempresentasikan peran dan kebiasaannya yang unik, serta mengetahui bahwa setiap individu memiliki prinsip dan nilai yang berbeda. Pemahaman tentang peran, kebiasaan, prinsip, dan nilai ini akan berpengaruh pada dinamika kepribadian remaja hingga sepanjang hidupnya. Oleh karena itu, perlu adanya psikoedukasi agar siswa mengetahui pentingnya identitas diri, mengetahui cara menemukan identitas diri, mengetahui konsep role confusion dalam psikososial, dan menghormati nilai serta prinsip yang berbeda. Berangkat dari permasalahan "mudah terbawa arus pergaulan", kegiatan dilakukan di SMP Negeri 11 Semarang, partisipan dalam kegiatan ini berjumlah 32 siswa. Metode yang digunakan dalam kegiatan ini adalah psikoedukasi. Psikoedukasi telah dilaksanakan pada 21 November 2019. Kegiatan yang dilakukan meliputi pre-test dalam bentuk permainan, pemberian materi mengenai identitas diri, dan post-test untuk mengetahui pemahaman siswa. Hasil kegiatan psikoedukasi ini siswa mengetahui definisi identitas diri, siswa menyadari pentingnya identitas diri, memahami konsep role confusion. Saran kegiatan ini agar dilakukan secara berkelompok, yaitu membentuk support group, penanganan personal melalui konseling, dan melaksanakan follow up.
\end{abstract}

Kata Kunci: Remaja, Identitas Diri, Psikososial

\section{PENDAHULUAN}

Setiap individu dilahirkan dengan keunikan atau ciri khas yang membuat mereka berbeda dengan individu lainnya. Keunikan tersebut dikenal juga dengan identitas. Identitas adalah hal yang penting karena pada masa remaja, perkembangan fisik, keterampilan kognitif, dan harapan sosial memungkinkan remaja untuk membangun masa depan mereka. Identitas sendiri terbentuk dari banyak hal, misalnya keadaan ekonomi, sosial, budaya, dan pengalaman seseorang.

Menurut Erikson (dalam Hasanah, 2013), identitas diri yang baik dipengaruhi oleh lingkungan sosial, reference group, dan tokoh idola. Selain itu orang tua dan keluarga juga berperan penting dalam membuat individu menumbuhkan perasaan terhadap diri mereka. Namun keadaan berbanding terbalik dengan yang dialami oleh siswa dan siswi di SMP Negeri 11 Kota Semarang. Kebanyakan dari mereka berasal 
dari keluarga yang tidak harmonis atau broken home, ada juga yang dititipkan pada saudara terdekat karena orang tua bekerja diluar kota Semarang. Sehingga sejak kecil mereka dirawat oleh saudara terdekat seperti nenek, kakek, paman, atau bibi. Pola asuh yang didapatkan oleh siswa-siswi ini sering kali membuat mereka merasa kurang kasih sayang dan perhatian. Keadaan ini menyebabkan suatu fenomena yang termasuk dalam kenakalan remaja.

Latar belakang keluarga yang berbedabeda dari siswa dan siswi di sekolah tersebut, sebagian besar dari mereka memiliki ekonomi menengah ke bawah. Orang tua mereka banyak yang bermatapencaharian sebagai pedagang dan buruh pabrik. Keadaan ekonomi seperti ini menyebabkan rendahnya kesadaran akan kesejahteraan psikologis anggota keluarga. Siswa-siswi yang berasal dari keluarga broken home ditambah lagi jika mereka berasal dari kalangan ekonomi menengah ke bawah tersebut sebagian besar melakukan hal-hal yang menyimpang dari norma yang ada di masyarakat. Seperti adiksi alkohol, sering bolos sekolah, bahkan ada juga yang mengalami kehamilan diluar nikah. Perilaku ini sebenarnya dilakukan untuk mencari kesenangan di luar rumah, namun karena kurangnya perhatian dan pengawasan orang tua di masa remaja mereka, terjadilah halhal yang berkaitan dengan kenakalan remaja.

Permasalahan nyata yang dialami siswasiswi SMP Negeri 11 Semarang adalah mudah lunturnya identitas mereka ketika beinteraksi dengan lingkungan sosial yang berbeda-beda. Hal yang melatarbelakangi permasalahan tersebut seperti sudah dijelaskan sebelumnya adalah kondisi keluarga yang tidak harmonis, pola asuh yang tidak stabil atau sering berubahubah, dan kurangnya kesadaran akan kesejahteraan psikologis anak.

Sumara, Humaedi, dan Santoso (2017), dalam jurnal berjudul "Kenakalan Remaja dan Penanganannya" menyampaikan bahwa masa remaja adalah masa mencari identitas. Pencarian identitas tersebut dilakukan dengan cara mencoba-coba banyak hal, yang seringkali malah menjerumuskan remaja pada suatu kesalahan. Erik Erikson, seorang psikoanalis mengembangkan suatu teori yang melihat perkembangan dengan mengidentifikasi dan membedakan isu pokok dari setiap rentang usia. Sehingga pengalaman di masa dewasa dapat digambarkan sebagai reinterpretasi dari periode sebelumnya. Teori tersebut kemudian dikenal dengan psikososial. Dalam teori psikososialnya Erikson menyampaikan delapan tahap perkembangan, dan bagi individu pada rentang usia 12 sampai 18 tahun mengalami tahap identity vs role confusion. Pada tahap tersebut, individu mulai mengembangkan identitas dirinya yang unik, namun tetap harus sesuai dengan norma masyarakat (Morelli, 2020). Bila individu tidak mampu menemukan dirinya, ia akan mengalami kekaburan atau kebingungan peran. Namun pada dasarnya setiap manusia melewati kedua kutub dalam satu tahap psikososial. Artinya, individu di masa remajanya akan melewati tahap mencari identitas diri dan juga menemukan kebingungan peran (Newman \& Newman, 2012). Kebanyakan remaja harus melalui masa-masa sulit sebelum memasuki masa dewasanya. Sejumlah remaja mengalami permasalahan self-esteem, penurunan well-being, depresi, cemas dan aktivitas destruktif baik personal maupun sosial (Schwartz, Luyckx, Beyers, \& Soenens, 2011)

Konsep identitas diri yang abstrak kemudian dioperasionalkan oleh beberapa peneliti. Salah satunya yaitu Berzonsky (dalam Muttaqin \& Ekowarni, 2016), tentang model gaya identitas yang menggambarkan cara individu dalam eksplorasi identitas dirinya dan membuat keputusan. Beberapa gaya tersebut 1) Gaya informatif; yaitu mencari, mengolah, dan mengevaluasi informasi yang sesuai dengan identitas. 2) Gaya normatif; yaitu melakukan internalisasi dari nilai dan petunjuk significant others-nya. 3) Menunda-menghindar; yaitu individu enggan untuk menghadapi krisis psikososial pada rentang usianya.

Psikoedukasi Proteksi Diri Dalam Berinteraksi (PRODIKSI) ini dilakukan untuk 
upaya preventif dari kebingungan peran tersebut. Karena pada setiap krisis psikososial terdapat central process yang dapat membantu seorang individu untuk menyelesaikan krisis tersebut dengan cara mengenali tekanan sosial dan ekspektasi dari tahap psikososial yang baru, serta memberi makna personal terhadap tekanan sosial dan ekspektasi tersebut (Newman \& Newman, 2012). Tujuan psikoedukasi PRODIKSI adalah memberi pengetahuan tentang cara-cara menemukan identitas diri, mengetahui pentingnya identitas diri, dan mengetahui dampak dari kekaburan atau kebingungan peran. Karena dengan sense of ego identity yang kuat, seseorang akan menerima dirinya dengan baik sehingga tingkat kecemasan juga akan menurun (Orenstein \& Lewis, 2020) dan yang terpenting individu dapat menjadi individu yang percaya diri, kemudian mampu bersosialisasi dengan individu lain tanpa kehilangan identitasnya (Morelli, 2020).

\section{METODE}

Pelaksanaan program PRODIKSI dilakukan dengan metode psikoedukasi. Menurut Kode Etik Psikologi Indonesia (2010), psikoedukasi merupakan kegiatan yang dilakukan untuk meningkatkan pemahaman dan/atau keterampilan sebagai usaha pencegahan dari munculnya dan/atau meluasnya gangguan psikologis di suatu kelompok, komunitas atau masyarakat. Psikoedukasi diberikan dalam bentuk permainan dan ceramah, serta dilakukan selama 2 jam pelajaran, yaitu kurang lebih 90 menit. Dimulai dari persiapan, perkenalan, permainan, penyampaian materi, diskusi, dan penutup.

Permainan dan ceramah menjadi salah satu metode dalam psikoedukasi yang diberikan karena program ini dilakukan di tengah kegiatan belajar mengajar, sehingga metode bermain diberikan agar siswa mendapat suasana belajar yang baru. Selain itu juga agar program ini dapat menjadi wadah refreshing bagi siswa namun tetap mendapatkan pelajaran yang penting bagi kehidupan mereka di masa remaja. Peserta dalam program psikoedukasi PRODIKSI adalah siswasiswi kelas 9 SMP Negeri 11 Kota Semarang, yang berjumlah 32 orang, terdiri dari 15 perempuan dan 17 laki-laki.

Tabel 1. Modul Psikoedukasi PRODIKSI

\begin{tabular}{|c|c|c|}
\hline Sesi & $\begin{array}{l}\text { Pokok } \\
\text { Bahasan }\end{array}$ & Tujuan \\
\hline $\begin{array}{l}\text { "Kenali } \\
\text { diriku" }\end{array}$ & - & $\begin{array}{c}\text { Brainstormi } \\
n g, \\
\text { meningkatkan } \\
\text { fokus siswa, } \\
\text { siswa menggali } \\
\text { hal unik dalam } \\
\text { dirinya. }\end{array}$ \\
\hline \multirow[t]{2}{*}{$\begin{array}{l}\text { Psikoedukas } \\
\text { i PRODIKSI }\end{array}$} & $\begin{array}{c}\text { Konsep } \\
\text { identitas } \\
\text { diri, } \\
\text { konsep } \\
\text { psikososial } \\
\text { (Identity vs } \\
\text { role } \\
\text { confusion), } \\
\text { konsep } \\
\text { model gaya } \\
\text { identitas, } \\
\text { konsep } \\
\text { status } \\
\text { identitas. }\end{array}$ & $\begin{array}{c}\text { Siswa } \\
\text { mengenali } \\
\text { konsep dari } \\
\text { materi yang } \\
\text { akan dibahas, } \\
\text { siswa } \\
\text { mengetahui } \\
\text { sampai dimana } \\
\text { proses } \\
\text { perkembangann } \\
\text { ya di masa } \\
\text { remaja. }\end{array}$ \\
\hline & $\begin{array}{c}\text { Cara } \\
\text { menemuka } \\
\text { n dan } \\
\text { membentu } \\
\text { k identitas } \\
\text { diri }\end{array}$ & $\begin{array}{l}\text { Meningkatk } \\
\text { an pengetahuan } \\
\text { siswa tentang } \\
\text { sumber-sumber } \\
\text { untuk } \\
\text { menemukan } \\
\text { dan membentuk } \\
\text { identitas diri. }\end{array}$ \\
\hline
\end{tabular}




\begin{tabular}{|c|c|}
\hline $\begin{array}{l}\text { Dampa } \\
\text { k menunda } \\
\text { dan } \\
\text { menghinda } \\
\text { r dari } \\
\text { pembentuk } \\
\text { an identitas } \\
\text { diri }\end{array}$ & $\begin{array}{c}\text { Meningkatk } \\
\text { an kesadaran } \\
\text { peserta akan } \\
\text { pentingnya } \\
\text { menemukan } \\
\text { identitas diri. } \\
\text { Agar mereka } \\
\text { mampu } \\
\text { berinteraksi } \\
\text { dengan siapa } \\
\text { saja tanpa } \\
\text { menghilangkan } \\
\text { identitas dirinya. }\end{array}$ \\
\hline
\end{tabular}

Proses psikoedukasi PRODIKSI ini dimulai dengan meminta izin kepada sasaran program, yaitu Wakil Kepala Sekolah Bidang Kesiswaan dan Guru Bimbingan Konseling SMP Negeri 11 Kota Semarang. Setelah mendapatkan izin, proses dilanjutkan dengan melakukan assessment awal kepada Wakil Kepala Sekolah Bidang Kesiswaan dan Guru Bimbingan Konseling SMP Negeri 11 Kota Semarang. Assessment tersebut dilakukan dengan wawancara dan observasi.

Data assessment yang sudah didapat menjadi dasar untuk mencari penyelesaian masalah yang terjadi pada sekolah tersebut. Penulis mulai mencari materi serta literatur yang berkaitan dari jurnal penelitian terdahulu dan buku-buku referensi pendukung lainnya. Kemudian dikembangkan dalam bentuk permainan dan materi. Selanjutnya memasuki proses intervensi dilakukan dengan metode game, ceramah, dan diskusi dalam bentuk tanya jawab.

Penyampaian materi terkait identitas diri diawali dengan pemberian game yang bertajuk "Ciri Khasku". Dalam game ini tiap individu menuliskan 3 ciri khasnya masing-masing pada secarik kertas yang nantinya akan ditukar secara acak dengan siswa lainnya untuk ditebak siapa pemilik asli dari ciri khas yang tertulis tersebut. Game ini memiliki tujuan untuk mengungkap sejauh mana siswa mengenal siapa diri mereka dan keunikan apa yang membedakan mereka dari individu yang lain.

Kemudian dilanjutkan dengan metode ceramah, menjelaskan maksud dari game yang telah dilakukan serta memberikan materi penjelasan mengenai teori identitas diri. Teori diberikan dengan tahapan 1) memberikan definisi dari identitas diri, model gaya identitas, dan status identitas; 2) Memberikan definisi psikososial dan identity vs role confusion; 3) Melakukan sedikit diskusi terkait proses pembentukan identitas yang sudah dilalui oleh siswa; 4) Memberi informasi cara-cara yang dapat dilakukan untuk menemukan identitas diri siswa; 5) Memberi penjelasan dampak jika terus menunda bahkan menghindar dari proses pembentukan identitas; 6) Diskusi berupa tanya jawab dengan siswa dan kemudian diakhiri dengan penutup. Proses terakhir dilakukan evaluasi bersama dengan Guru Bimbingan Konseling SMP Negeri 11 Kota Semarang.

Tabel 2. Evaluasi Sesi-Sesi Psikoedukasi Prodiksi

\begin{tabular}{|c|c|c|}
\hline Sesi & $\begin{array}{l}\text { Pokok } \\
\text { Bahasan }\end{array}$ & Evaluasi \\
\hline $\begin{array}{l}\text { "Kenali } \\
\text { diriku" }\end{array}$ & - & - \\
\hline $\begin{array}{l}\text { Psikoeduka } \\
\text { si PRODIKSI }\end{array}$ & $\begin{array}{l}\text { Konsep } \\
\text { identitas } \\
\text { diri, konsep } \\
\text { psikososial } \\
\text { (Identity vs } \\
\text { role } \\
\text { confusion), } \\
\text { konsep } \\
\text { model gaya } \\
\text { identitas, }\end{array}$ & $\begin{array}{l}\text { Siswa } \\
\text { sulit fokus, } \\
\text { sebaiknya } \\
\text { materi } \\
\text { diberikan } \\
\text { dalam } \\
\text { kelompok- } \\
\text { kelompok } \\
\text { kecil. }\end{array}$ \\
\hline
\end{tabular}




\begin{tabular}{|c|c|}
\hline $\begin{array}{c}\text { konsep } \\
\text { status } \\
\text { identitas }\end{array}$ & \\
\hline $\begin{array}{c}\text { Cara } \\
\text { menemukan } \\
\text { dan } \\
\text { membentuk } \\
\text { identitas } \\
\text { diri }\end{array}$ & $\begin{array}{l}\text { Diperluk } \\
\text { an follow up } \\
\text { bersama } \\
\text { Guru BK dan } \\
\text { orang tua } \\
\text { bagi siswa- } \\
\text { siswa yang } \\
\text { memiliki } \\
\text { hambatan. }\end{array}$ \\
\hline $\begin{array}{c}\text { Dampak } \\
\text { menunda } \\
\text { dan } \\
\text { menghindar } \\
\text { dari } \\
\text { pembentuka } \\
\text { n identitas } \\
\text { diri }\end{array}$ & $\begin{array}{c}\text { Diperluk } \\
\text { an diskusi } \\
\text { yang lebih } \\
\text { privat untuk } \\
\text { mendalami } \\
\text { hambatan } \\
\text { yang dialami } \\
\text { siswa. }\end{array}$ \\
\hline
\end{tabular}

\section{HASIL DAN PEMBAHASAN}

Remaja atau adolescence berarti 'tumbuh' atau 'tumbuh menjadi dewasa' (Hurlock, 2009:206). Istilah remaja mempunyai arti mencakup kematangan mental, emosional, sosial, dan fisik. Dalam proses mencapai kematangan mental, emosional, dan fisik tersebut terdapat tahap mencari identitas diri.

Materi tentang identitas diri diawali dengan game yang meminta setiap siswa menuliskan tiga ciri khas dirinya pada secarik kertas. Kemudian kertas tersebut dikumpulkan, lalu fasilitator game memberikan beberapa kertas secara acak kepada siswa yang bukan pemiliknya, mereka diminta untuk menebak individu yang ada di dalam kertas tersebut. Dari lima siswa yang diminta menebak, hanya tiga yang berhasil menjawab. Dua siswa lainnya belum bisa menebak karena ciri khas yang ada dalam kertas tersebut masih terlalu umum bagi mereka.

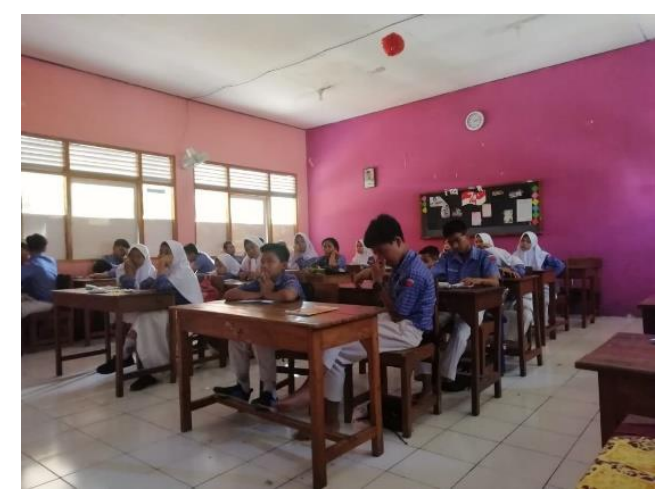

Gambar 1. Dokumetasi Sesi Kenali Diriku

Mengatasi hal tersebut fasilitator game memberi instruksi untuk game yang sama namun siswa diminta menuliskan ciri khas yang lebih spesifik atau benar-benar melekat dengan diri mereka. Kemudian lima siswa diminta menebak siswa lainnya dari kertas yang telah diacak, dan lagi-lagi masih ada yang belum bisa menjawab.

Game tersebut adalah salah satu cara assessment singkat untuk mengetahui sejauh mana siswa mengenali siapa dirinya dan keunikan apa yang membuatnya berbeda dari temannya. Erikson (dalam Papalia, 2008) mendefinisikan identitas sebagai konsepsi tentang diri, penentuan tujuan, nilai, dan keyakinan yang dipegang teguh oleh seseorang. Dari definisi ini siswa dan siswi di kelas 9F tersebut secara umum belum menemukan konsepsi tentang diri mereka, dan juga belum memiliki keyakinan yang dipegang teguh. Hal ini dapat dilihat dari fenomena "terbawa arus" yang terjadi disana. Siswa dan siswi tersebut menganggap bahwa nilai apapun yang ada di 
tengah masyarakat pasti cocok dengan diri mereka.

Ditinjau dari dimensi identitas diri menurut Erikson (dalam Hasanah, 2013) salah satu nya adalah 1) Struktural, remaja memiliki perencanaan masa depan; 2) Adaptif, remaja memiliki keterampilan khusus, kemampuan, dan kekuatan yang sesuai dengan masyarakat dimana mereka tinggal; 3) Timbal balik psikososial, remaja mampu memberikan kontribusi pada lingkungan sosialnya; 4) Status eksistensial, remaja mencari arti hidup mereka. Dari keempat hal tersebut siswa-siswi di SMP Negeri 11 Kota Semarang termasuk belum menemukan identitas diri mereka.

Perlu dipahami bahwa hal ini merupakan bagian dari krisis psikososial yang dialami setiap individu pada usia 12 sampai 18 tahun. Karena individu tersebut masih berproses untuk akhirnya dapat memenuhi tekanan sosial dan ekspektasi baru pada tahap identity vs confusion. Seorang individu dapat dikatakan berhasil melalui suatu tahap psikososial dengan cara yang sehat (Tsang, Hui \& Law, 2012) atau krisis telah selesai jika individu sudah mendapatkan identitasnya, ia telah mempertimbangkan berbagai tujuan dan menghargai, menerima dan menolak beberapa orang, serta memahami siapa mereka sebagai pribadi yang unik (Erikson, dalam Upreti, 2017).

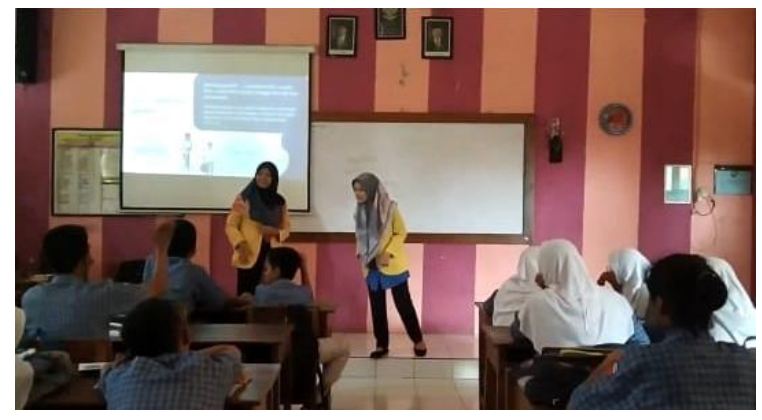

Gambar 2. Dokumentasi Sesi Psikoedukasi PRODIKSI

Proses krisis psikososial pada siswasiswi kelas 9F SMP Negeri 11 Kota Semarang dilakukan dengan model gaya identitas yang berbeda-beda. Anak yang tidak tinggal bersama orang tua kandung dan terbiasa untuk lepas dari pengawasan yang ketat cenderung mempunyai model gaya identitas menunda-menghindar. Mereka beranggapan bahwa hidup ini tidak perlu direncanakan, suatu saat identitas diri tersebut akan terbentuk dengan sendirinya. Dunkel, dkk. (dalam Tsang, Hui \& Law, 2012) menyampaikan bahwa model gaya identitas menundamenghindar lebih dipengaruhi oleh kepribadian seseorang ketimbang fungsi keluarga. Kemudian anak yang tinggal bersama kakek, nenek, paman, atau bibi, mereka mempunyai model gaya identitas gaya informatif. Karena pola asuh atau nilai-nilai dari orang yang merawat mereka dianggap tidak cocok dengan kepribadian anak. Model gaya identitas normatif dipengaruhi oleh kepribadian dan fungsi keluarga. Sehingga anak ingin mencari nilai-nilai baru ataupun gaya hidup baru yang lebih mereka sukai namun masih sesuai dengan nilai yang ditanamkan keluarga mereka. Anak dengan model gaya informatif cenderung dipengaruhi oleh lingkungan sosial dan tokoh idola mereka dalam membentuk identitasnya (Erikson, 1989). Anak yang tinggal bersama orang tua kandung mempunyai model gaya identitas normatif, mereka dengan mudah menerima nilai-nilai dari orang tua. Hal ini sesuai dengan budaya patriarki di Asia (SpencerRodgers, dkk., dalam Tsang, Hui \& Law, 2012) dimana orang tua (khususnya ayah) memiliki ekspektasi yang tinggi terhadap anak-anaknya untuk menjaga nama baik keluarga dan melanjutkan bisnis keluarga. Sehingga sejak kecil anak terus diberikan contoh nilai dan norma yang harus dilakukan di tengah masyarakat. Model gaya identitas ini dipengaruhi oleh faktor kognitif, sosial, dan psikologis seperti kepribadian. Bahkan beberapa penelitian mendalami pengaruh anggota keluarga, guru, dan teman sebaya (Tsang, Hui \& Law, 2012).

Tingkat pencapaian identitas diri juga dapat dilihat dari status identitas yang disampaikan oleh Marcia (dalam Pellerone, Spinelloa, Sidoti, \& Micciche, 2015; Upreti, 2017) yaitu, 1) Achievement, pada tahap ini individu telah berhasil menyelesaikan krisis 
psikososialnya dengan membuat komitmen, mempunyai suatu kepercayaan, dan nilai yang dipegang; 2) Moratorium, pada tahap ini individu masih dalam proses membentuk identitas dirinya dengan memahami beberapa pilihan yang ada dalam kehidupan mereka; 3) Foreclosure, tahap ini berarti seorang remaja menerima nilai tradisional dan normal kultural daripada mencari nilai hidupnya sendiri. Foreclosure ditandai dengan komitmen yang kuat dan sedikit eksplorasi; 4) Diffusion, tahap ini menggambarkan seorang remaja yang tidak menyelesaikan krisis psikososialnya. Individu tersebut gagal untuk membuat komitmen akan suatu tujuan atau nilai.

Permasalahan yang timbul dalam interaksi sosial dari siswa dan siswi yang masih mengalami kebingungan peran adalah melakukan kenakalan remaja. Ada siswa yang drop out karena hamil diluar nikah, ada siswa yang bolos untuk nongkrong dan minum minuman keras, dan ada juga siswa yang bergaul dengan anak-anak punk. Berdasarkan penelitian Rashmi Upreti (2017), keluarga dan teman sebaya sangat mempengaruhi pembentukan identitas.

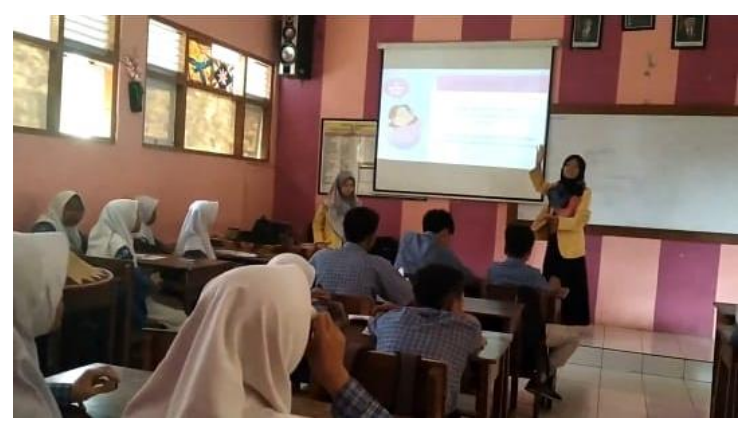

Gambar 3. Dokumentasi Sesi Psikoedukasi PRODIKSI

Keluarga (baik secara biologis atau tidak) mempengaruhi pembentukan identitas. Interaksi yang terjadi dengan individu yang sedang melewati proses pembentukan identitas adalah hal yang mempengaruhi. Jika keluarga tidak mampu memberikan pengaruh positif, remaja akan mengalami kebingungan peran atau role confusion. Menjadi bagian dari suatu keluarga yang tidak bisa dipilih ketika seseorang lahir, maupun menjadi bagian dari kelompok teman sebaya yang bisa dipilih, sama-sama memiliki sisi positif dan negatif. Hal yang menentukan identitas diri seseorang menjadi baik atau tidak adalah cara individu bersosialisasi dalam cara yang positif, membangun komunikasi yang baik, dan berani berkomitmen. Pellerone, Spinelloa, Sidoti, dan Micciche (2015) menyampaikan bahwa adanya korelasi positif antara kontrol pengasuhan orang tua dan gaya relasi cemas, dan ada korelasi antara level afeksi pengasuhan dan gaya relasi detached.

Teman sebaya juga memiliki pengaruh positif dan negatif. Pengaruh positif yang diberikan dapat berupa motivasi akademik, peningkatan empati, kepemimpinan, dan lainnya. Sedangkan pengaruh negatif yang diberikan dapat berupa keterlibatan dalam narkoba, minuman keras, vandalisme, pencurian, dan perilaku berisiko lainnya. Tentunya gaya relasi dengan teman sebaya ini juga bergantung pada persepsi relasi remaja dengan orang tuanya (Pellerone, Spinelloa, Sidoti, \& Micciche, 2015).

Cara lain untuk mengatasi permasalahan yang diperlukan siswa-siswi di SMP Negeri 11 Kota Semarang adalah, 1) Belajar meningkatkan self-esteem. Harter (dalam Tsang, Hui \& Law, 2012) mengatakan bahwa self-esteem dalam mempengaruhi pembentukan identitas dan emosi yang berkaitan dalam pembentukan tersebut. Self-esteem yang positif akan melahirkan selfevaluation yang positif pula. Self-evaluation yang positif memberikan energi pada seseorang ketika melewati masa krisis psikososial di usia remaja. Karena tidak semua hal yang terjadi dalam krisis psikososial identity vs role confusion dapat dengan mudah berubah atau diatasi; 2) Terus melakukan eksplorasi dan komitmen. Remaja dapat memutuskan peran mereka melalui pengalaman yang memberi mereka kesempatan untuk belajar memahami keadaan yang baru dan belajar menyelesaikan suatu masalah. Cara seorang individu memahami dan menyelesaikan suatu masalah membuat mereka mampu menilai sesuatu secara mendalam dengan banyak sudut 
pandang, dari kemampuan tersebut kemampuan stress coping dan problem solving mereka akan semakin efektif dan efisien. Tentunya kemampuan tersebut sangat membantu dalam menghadapi masalah yang muncul ketika proses pembentukan identitas diri. 3) Mengurangi selfdiscrepancies. Self-discrepancies adalah ketidakseimbangan antara self (diri), real self (kenyataan tentang diri seseorang), dan perceived self (pandangan seseorang atau orang lain tentang dirinya). Ketidakseimbangan ini sering kali menyebabkan masalah emosional dan perilaku dalam krisis psikososial. Hal yang dapat dilakukan untuk menguranginya adalah mengidentifikasi hal-hal yang wajar menyebabkan self-discrepancies tersebut. Individu juga dalam menerapkan komitmen dan meningkatkan self-esteem. Dukungan dari teman sebaya dan juga guru di sekolah untuk memberi pengertian tentang hal-hal yang terjadi selama krisis psikososial di masa remaja juga dapat membantu individu dalam pembentukan identitas dirinya (Tsang, Law \& Hui, 2012). Selain itu dibutuhkan juga kerjasama dari orang tua mereka di rumah dalam memberikan pengawasan terhadap anak-anak mereka.

Sampai dilakukannya psikoedukasi ini belum ada upaya untuk menyelesaikan masalah dalam krisis psikososial identity vs role confusion yang dialami oleh siswa. Oleh karena itu psikoedukasi PRODIKSI dapat dilanjutkan dan dikembangkan dengan membuat small support group dibersamai dengan memberi pelatihan untuk meningkatkan self esteem, memberi wadah-wadah untuk melakukan eksplorasi yang positif, dan upaya lainnya.

\section{KESIMPULAN}

Melalui pengabdian ini didapatkan hasil bahwa rata-rata siswa di SMP Negeri 11 Kota Semarang masih berada pada tahap kebingungan peran. Namun perlu dipahami bahwa hal ini merupakan bagian dari krisis psikososial yang dialami setiap individu pada kisaran usia 12-18 tahun. Siswa masih dalam tahapan mempersiapkan dirinya untuk menghadapi tekanan sosial dan ekspektasi yang baru pada fase perkembangan psikososial ini (identity vs role confusion).

Melalui pengabdian ini ditemukan pula upaya-upaya untuk mengatasi permasalahan terkait identitas diri yang terjadi pada siswa SMP Negeri 11 Kota Semarang diantaranya yaitu, belajar meningkatkan self-esteem, terus melakukan eksplorasi dan komitmen, serta mengurangi self-discrepancies. Bantuan dari orang tua dan guru di sekolah atau siapapun yang menjadi sosok yang disegani juga dapat membantu proses pembentukan identitas siswa.

Adapun saran untuk penanganan atau pendampingan berkelanjutan, perlu dilakukan pembentukan small support group dan follow up secara berkala. Jenis pendampingan lainnya, dapat dilakukan secara personal yaitu dengan konseling.

\section{UCAPAN TERIMAKASIH}

Ucapan terima kasih kami sampaikan kepada SMP Negeri 11 Kota Semarang beserta seluruh jajaran guru dan pegawai, terutama bagi Wakil Kepala Sekolah Bidang Kesiswaan dan Guru Bimbingan Konseling yang telah banyak membantu kami dalam pelaksanaan, memberi saran, dan mendukung kelancaran berjalannya pengabdian ini.

\section{REFERENSI}

Newman, B. M., \& Newman, P. R. (2012). Development Through Life: A Psychosocial Approach. Wadsworth: Cengage Learning.

Sumara, D. S., Humaedi, S., \& Santoso, M. B. (2017). Kenakalan Remaja Dan Penanganannya. Jurnal Penelitian \& PPM, 347-353.

Muttaqin, D., \& Ekowarni, E. (2016). Pembentukan identitas remaja di 


\section{Yogyakarta. Jurnal Psikologi, 43(3), 231-247.}

Erikson, Erik H. (1989). Identitas dan Siklus Hidup Manusia; Bunga Rampai 1. Jakarta: PT. Gramedia.

Hasanah, U. (2013). Pembentukan Identitas Diri dan Gambaran Diri pada Remaja Putri Bertato di Samarinda. E-journal Psikologi, 1(2), 177-186.

Hurlock, E. B. (2009). Psikologi Perkembangan. Jakarta: Penerbit Erlangga.

Indonesia, H. P. (2010). Kode Etik Psikologi Indonesia. Jakarta: Pengurus Pusat Himpunan Psikologi Indonesia.

Morelli, A. O. (2020, Maret 18). Erik Erikson and Self-Identity. Diambil kembali dari Helen Farabee Centers: https://www.helenfarabee.org/

Orenstein, G. A., \& Lewis., L. (2020). Eriksons Stages of Psychosocial Development. East Florida: StatPearls.

Papalia, D. E., Sally W., \& Ruth D. (2008). Human Development (Psikologi
Perkembangan). Jakarta: Kencana
Prenada Media Group.

Pellerone, M., Spinelloa, C., Sidoti, A., Micciche, S. (2015). Identity, perception of parentadolescent relation and adjustment in a group of university students. Procedia social and behavioral sciences, 190, 459464.

Schwartz, S. J., Beyers, W., Luyckx, K., Soenens, B., Zamboanga, B. L., Forthun, L. F., ... \& Whitbourne, S. K. (2011). Examining the light and dark sides of emerging adults' identity: A study of identity status differences in positive and negative psychosocial functioning. Journal of youth and adolescence, 40(7), 839-859.

Tsang, S. K., Hui, E. K., \& Law, B. (2012). Positive identity as a positive youth development construct: A conceptual review. The Scientific World Journal, 18.

Upreti, R. (2017). Identity Construction: An Important Issue Among Adolescents. IOSR Journal of Humanities and Social Science, 54-57. 